\title{
PARTY-POLITICAL PEASANT-CENTRAL DISCOURSE IN THE DAY OF THE UKRAINIAN REVOLUTION 1917-1921: IDEOLOGICAL TYPES AND MOBILIZATION POSSIBILITIES
}

\section{Lozovyi V.S.}

\section{INTRODUCTION}

At the beginning of the twentieth century, sub-Russian Ukraine was mostly an agrarian society, where the peasantry dominated the social structure and played a significant role in the economy. Thus, the urgency of this research problem is due to the attention of modern peasant studies to the formation of the political doctrine of agrarianism in Ukraine, its important component - the party-political discourse of the revolutionary period 1917-1921, which reflected in linguistic forms ideological and worldview aspects of interaction between peasantry and political forces and movements that were at the centre of state-building and socio-political processes.

The author aims to identify the party-political peasant-centric discourse that represented the ideological varieties of agrarianism. To do this, we need to solve the following tasks - to find out the types of discourses and identify their mobilization opportunities in the countryside during the Ukrainian Revolution of 1917-1921.

The peasant-centric aspect of this problem in the context of the study of the ideology of agrarianism was covered in the works of domestic historians. Considering the subjective factor of the agrarian issue as one of the preconditions of the revolutionary events of 1917-1921, S. Kornovenko concluded that a new active subject appeared on the forefront of history the peasant-ideoman ${ }^{1}$. Highlighting the "hamlet philosophy" of P. Kulish, the author stated that it was consistent with the peasant consciousness and became the foundation of the semantic basis of Ukrainian agrarianism of the first third of the twentieth century ${ }^{2}$. The formation of Ukrainian agrarianism as a kind of Eastern European agrarianism was studied by S. Kornovenko and Y. Pasichna". Examining the "grain grower ideology" of V. Lypynsky,

\footnotetext{
${ }^{1}$ Корновенко, С.В. Суб'єктний складник аграрного питання як одна з передумов Української революції 1917-1921 рр. Украӥнський історичний журнал. 2017. № 4. C. 83-94.

${ }^{2}$ Корновенко С. Хутірська філософія П. Куліша: біля джерел українського аграризму. Украӥнський історичний журнал. 2020. № 5. С. 64-76.

${ }^{3}$ Kornovenko S., Pasichna Y. Eastern european agrarianism. Ukrainian intellectual space in the late 19-th and early 20-th centuries. Український селянин. 2019. Вип. 22. С. 24-29.
} 
K. Galushko came to the conclusion that the national varieties of agrarianism represent an attempt to solve a set of socio-political problems of agrarian society, which suffered from the effects of modernization ${ }^{4}$. However, in this aspect the author did not consider this topic.

The study examines Ukrainian parties, organizations, movements that operated in Ukraine and whose political activities had a pronounced peasantcentric character. In determining the types of party-political peasant-centric discourses, the following criteria are taken: 1) principles of solving the agrarian issue; 2) vision of the peasantry in the context of power and the state and the implementation of models of their construction.

By "discourse" we mean language (text), which contains a set of ideas, arguments and symbols used in practice by socio-political actors (parties, organizations, joint movements) during the revolutionary process.

We consider the party-political peasant-centric discourse in the context of the ideology of agrarianism. K. Galushko, defining the criteria for characterizing a certain doctrine as agrarianist, argues that agricultural ideology should emphasize the political "separatism" of the peasants and the separation of the peasant "third" way (outside of capitalism and communism) ${ }^{5}$. Since ideology is a discourse and is constructed by language, the means of such construction are linguistic elements, first of all supporting tokens, which represent the concepts of a certain ideological and worldview picture of the world. The study of partypolitical peasant-centric discourse is conducted mainly on the basis of analysis of programs of political parties, organizations and associations, statements and works of politicians, publications in the press, speeches at rallies and other meetings, congressional decisions, materials of parties and organizations. In covering and analysing the texts of various political parties and forces, we pay special attention to the so-called "manifestative vocabulary" (land, workers, grain growers, socialization, property, bourgeoisie, etc.), which is the main feature of a socially significant type of discourse and allows adequately assess political declarations and aspirations of individual political forces.

The party-political peasant-centric discourse of the revolutionary period of 1917-1921 is defined by us as a set of ideological slogans and sociocultural values, worldviews, strategies and tactics, speech-semantic component of the revolutionary process, whose mental-linguistic dominants are the fundamental role of agrarian issue and peasantry as a social basis of socio-political movements and the formation of power structures of statebuilding.

4 Галушко К. «Хліборобська ідеологія» В. Липинського у системі східноєвропейського аграризму. Украӥнський історичний збірник. 2000. № 2. С. 164-200.

${ }^{5}$ Ibid. C. 169, 178. 


\section{Left agrarianist peasant-centric discourse (USRP)}

An extremely important specific feature of the Ukrainian revolution was its pronounced peasant-agrarian factor. After the February Revolution of 1917, party building began in sub-Russian Ukraine. In an effort to strengthen their own social base, almost all political parties fought for the peasant, but above all - socialist-orientated parties. In April 1917, the Ukrainian Socialist-Revolutionary Party (USRP) was formed, which was significantly influenced by the Russian Socialist Revolutionaries. The USRP, noting that the national political movement has a peasant basis, declared itself the main defender of the interests of the peasants ${ }^{6}$.

The Ukrainian peasantry was impressed by the ideas of freedom, national self-government, equality, social justice, the priority of labour, and the abolition of landlordism. It is self-evident that the land was at the epicentre of all the aspirations of the peasants, and through the prism of solving the agrarian issue they looked at all other social problems. Thus, with the development of the revolution, the Ukrainian Socialist Revolutionaries tried to work out their own program, which would theoretically reflect the ideals and aspirations, and, consequently, the basic principles of peasant ideology. Without their own theoretical developments in the agrarian sphere, for some time they could not determine the socio-economic principles of agrarian reform, which would attract the attention of peasants to solve political issues.

We note the main theoretical developments of the Russian Socialist Revolutionaries, some of which became part of the ideology of the USRP, and some aspects (especially agrarian) were used by other parties and movements. The Socialist-Revolutionaries, following the populists, argued that the most harmonious conditions for the development of the human personality were created by agricultural labour and life, so, in view of this, the peasantry was the class best suited to the implementation of the socialist system. The basis of the SR ideology was the populist concept of a special path of Russia to socialism. This was due to the fact that in its development the country was between industrial and agrarian-colonial countries. They believed that in Russian capitalism, in contrast to the developed industrial countries, destructive tendencies prevailed, which were especially evident in agriculture. The class differentiation of society, according to SocialistRevolutionary theorists, was determined by attitudes toward labour and sources of income. Therefore, in the labour, revolutionary camp, they included workers, peasants and intellectuals - people who live by their

${ }^{6}$ Бевз Т. Між романтизмом і реалізмом (сторінки історії УПСР). Київ. Інститут політичних і етнонаціональних досліджень НАН України. 1999. С. 25-31. 
labour, without exploiting others. The peasantry was considered the main revolutionary force. At the same time, the duality of the social nature of this stratum was recognized, as the peasant is both a worker and an owner. The SRs substantiated the idea of the non-capitalist nature of the peasant economy by the alleged lack of exploitation of hired labour. The socialization of the land was one of the main goals of the revolution. It provided for the abolition of private ownership of land with a ban on buying and selling ${ }^{7}$. The land was to become a national property and was to be managed by people's self-government bodies. Equal labour use of land (provided that it is cultivated by one's own labour) and distribution according to consumer and labour norms were envisaged. The SRs believed that rural communities with their tradition of equal land use were tools for building socialism.

If we pay attention to the policy of the Ukrainian Socialist Revolutionaries, their line in solving the main agrarian problem for the peasantry is chaotic. In their periodicals, they declared an understanding of the fact that Ukrainian realities are different from Russian ones, because Ukrainians own mostly farmland and farmland, while the Great Russians are dominated by communal ones. However, at its Second Congress, the USRP took a course to socialize the land. M. Shapoval, a member of the USRP, wrote on this occasion: "The party did not have a separate project based on local Ukrainian data", but believed that the situation in Ukraine was similar to Russia's. Accordingly, "socialization is a modification of the Russian redistributive community" 8 . Not only the Ukrainian right, but also the left parties were critical of the agrarian program of the USRP, which was based on the program provisions of the Russian Socialist Revolutionaries without taking into account Ukrainian realities. The question was asked: how can the socialization of the land be realized in Ukraine, if there is no domination of the Russian "cell of socialism" - the redistributive community9.

Since land was the main determinant of rights and justice for the peasant, the theme of land was at the forefront of peasant meetings and congresses: "socialization and comparison are underway". At the same time, it was

${ }^{7}$ Программа партии социалистов-революционеров. [1906 г.]. Сборник программ политических партий в России. Под ред. В. Водовозова. Вып. 3. СПб., 1906. C. 14-27. URL: http://docs.historyrussia.org/ru/nodes/74934-programma-partii-sotsialistovrevolyutsionerov-1906-g.

8 Шаповал М.Ю. Революційний соціялізм на Україні: [книга 1]. Відень : Борітеся - Поборете. 1921. С. 42-44.

9 Винниченко В. Відродження нації: (Історія української революції [марець 1917 р. грудень 1919 р.]). [в 3 ч.]. Київ-Відень. [Дзвін]. 1920. Ч. 1. С. 182.

${ }^{10}$ Корреспонденции. Черниговская земская газета. 1917. 2-16 мая (№ 35-36). С. 9. 
noted a certain individualism inherent in the Ukrainian national character, and that the community system inherent in the Russian is not to the liking of the Ukrainian. The SRs acknowledged that the difference between the Ukrainian provinces and the Russian ones in the greater development of the first institution of small private property.

The Ukrainian Socialist Revolutionaries carried out extensive propaganda and explanatory work among the population and tried to explain to the peasants the issues they did not know well: about the autonomy of Ukraine, about the Constituent Assembly, about the Land and Freedom Party, which defends the interests of the peasantry ${ }^{11}$. From the point of view of social psychology, the discourse of "Land and Freedom" was very important for the peasantry. The SRs called themselves the party of "Land and Freedom", which has long been associated in the minds of peasants with the desire for a certain ideal way of social life. Therefore, a wide range of peasants, who did not read the party program, but were attracted by the wellknown slogan of the populists "Land and Freedom - to the peasantry!", became supporters of the SRs.

An important negative discourse was the discourse of the enemies of the peasants, the enemies of the revolution. It was stated that "they are landlords, capitalists, merchants" and that "enemies are united", so the peasants must unite ${ }^{12}$. To ensure the influence of the masses of the peasantry on the initiative of the USRP created the Village Union, which was to become the only mass organization of the peasantry. The discourse "Village Union" was important for the peasants as a symbol of their unification, joint activity.

The revolution of 1917, sanctioning democracy, gave rise to a new political force - the will of the people. Therefore, in general democratic elections, power could be gained only by those political forces that would attract the peasantry to their side. From places wrote that "from whichever side you will start the organization of the county, you always come across peasants"13. The appeal to the masses, the legitimation of the revolutionary government and its decisions through democratic procedures, that is, through the "will of the people", was actively used by Ukrainian and Russian parties and organizations. The countryside became a space of public political activity and was flooded with agitators and propaganda materials. To explain to the peasantry the situation in the national, educational, cultural sectors,

11 Земельный вопрос. Голос села. Охтирка. 1917. 2 липня. (№ 1). С. 1.

12 Що таке селоспілка? Вільне слово. 1917. 5 липня (№ 7). С. 1.

13 Український національно-визвольний рух. Березень-листопад 1917 року. Документи і матеріали. Упоряд. : В. Верстюк (керівник) та ін. Київ : Видавництво імені Олени Теліги. 2003. С. 497. 
socio-political, economic requirements and means of implementing the program of the USRP, literature, the press, demonstrations, rallies, various courses, and "Prosvita" societies were organized. The first mass and popular Ukrainian daily publication was the newspaper "Narodnya Volya", the total circulation of which reached 200 thousand copies ${ }^{14}$.

As a result of powerful propaganda, the most influential socialist party in 1917 became the Ukrainian Socialist Revolutionaries, whose slogan of "socialization of agriculture" corresponded to the expectations of the poor peasantry, who were waiting for the "black redistribution" of landlord land. In the Central Rada, the Ukrainian Socialist Revolutionaries Party played one of the leading roles. In many towns and villages, the SRs were members of the Soviets and headed revolutionary self-government bodies. The number of the party grew (according to the newspaper "Borotba" of December 27 (14), 1918, the USRP had 375,000 members).

The priority of agrarian issues for the peasantry was also determined by the political dominance of the parties in the countryside, which declared a radical solution to the agrarian issue according to models acceptable to grain growers. The overwhelming majority of peasant congresses of various levels adopted the program of the Ukrainian Socialist Revolutionaries Party. It was stated that "this program can really unite our working peasantry, because it is very close to the peasants and corresponds to their worldview"15. Consideration of party policy through the prism of the agrarian issue led to the fact that the peasants did not accept other parties, which insisted on the transfer of land for ransom, because they believed that in fairness the land should pass to them for free.

The struggle for "land and freedom" had a certain influence on the formation of the political position, on the nature of socio-political activities of Ukrainian peasants. In anticipation of agrarian reform, they began to understand that the revolution did not give the peasants land, but only freedom and the right to vote, equal for all. Therefore, in order to get land, you need to vote for those who support the socialization program. Ukrainian parties and organizations explained to the peasants that in order for the people to receive "all the land and freedom", it was necessary for the Constituent Assembly (which was to authorize agrarian reform) and local

14 Ковалевський М. При джерелах боротьби: спомини, враження, рефлексії. Інсбрук. "Biblos". 1960. С. 267-268.

15 Український національно-визвольний рух. Березень-листопад 1917 року. Документи і матеріали. Упоряд. : В. Верстюк (керівник) та ін. Київ : Видавництво імені Олени Теліги. 2003. С. 394. 
institutions to vote for their lists ${ }^{16}$. In Ukraine, in the elections to the All-Russian Constituent Assembly, 64\% of the population voted for parties and organizations that represented the Ukrainian national liberation movement, had a majority in the Central Rada and defended the interests of the peasantry (especially the USRP with the Union). If we take the view that the results of the elections to the All-Russian Constituent Assembly reflected the schedule and the balance of political forces, the greatest influence in Ukraine at that time was enjoyed by the USRP. But later the party experienced an internal crisis caused by ideological differences, after which it split into several independent currents.

As for the construction of the state and power, the USRP in its program initially defended the idea of autonomy of Ukraine, but in 1918 it embarked on the path of independence. Ukrainian SRs understood how important it was for the peasant's consciousness to believe that only personal "labour" was the definition of a person's "social quality" as a master and legitimized any property. That is why they made the "labour principle" the cornerstone of their ideology and policy and based on it developed their state-political model. The Socialist-Revolutionaries demonstrated the construction of socialism on the basis of a "dictatorship of revolutionary democracy" or a "dictatorship of labour democracy"17. This meant "that power be exercised only by the working masses organized on the basis of democracy": peasants, workers and the working intelligentsia. The so-called non-working classes were not allowed to vote ${ }^{18}$. The peasants were in favour of the introduction of Soviets as local self-government bodies. Therefore, the basis for the formation of power from the bottom to the top the USRP identified "Councils": "Labour Councils" (former zemstvos) and the Council of Workers', Peasants' and Soldiers' Deputies. It was an ambivalent decision about the coexistence of general democratic and class authorities.

Legislatively, the "labour principle" of building power, according to which the working peasantry was to be the basis for the development of the Ukrainian state, was adopted in the period of the Directory of the UPR. This was explained by the fact that during the class democratic elections the representatives of the peasant majority would prevail in all power structures.

16 Український національно-визвольний рух. Березень-листопад 1917 року. Документи і матеріали. Упоряд. : В. Верстюк (керівник) та ін. Київ : Видавництво імені Олени Теліги. 2003. С. 903-904.

${ }^{17}$ Багатопартійна українська держава на початку XX ст.: Програмні документи перших українських політичних партій. Упор. В.С. Журавський. Київ : Пошук. 1992. C. 17.

${ }^{18}$ Шаповал М. Велика революція і українська визвольна програма. Виклади в Америці. Прага : Вільна Спілка. 1927. С. 89. 
In contrast to the "dictatorship of the proletariat", where power was to be in the hands of the workers, and in fact of the Bolshevik state (the communist way), and of general democratic elections, when the bourgeoisie (the capitalist way) could be in power, the SRs seemed to propose a "third way" of development of society and the state, without communist nationalization and the negative impact of the elements of the market and the exploitation of workers. Thus, the predominance of peasants in the Ukrainian agrarian society determined the ideology of building a national statehood in the form of the Ukrainian People's, i.e. Labour Republic (UPR) and the principles of class policy.

Thus, the main party-political discourses of the Ukrainian Socialist Revolutionaries were: "revolution", "land and freedom", "socialization", "abolition of private property", "working peasantry", "village union", "people's will", "democracy", "dictatorship of labour democracy", "victory of workers over the bourgeoisie", "Council of Workers', Peasants' and Soldiers' Deputies", etc. The USRP was one of the main national political forces in Ukraine, which sought to resolve the agrarian issue in favour of the peasants, and made the peasantry the social foundation of state-building.

\section{Far-left agrarianist peasant-centric discourse (Makhnovist movement)}

Left and far-left forces dominated the Ukrainian political space. After the February Revolution of 1917, N. Makhno expanded his activities in the south of Ukraine, which turned into a powerful peasant movement. At first, N. Makhno and his movement did not have their own political program. He was strongly influenced by anarchist ideas, but during the revolution an independent ideological search developed in N. Makhno his own system of views, a kind of symbiosis of anarchism, socialism and peasant pragmatism. N. Makhno understood that the correct slogans and practices for solving the agrarian issue would allow his political force to gain the support of the general peasantry. And although he considered himself an anarchist, he took the position of the Socialist-Revolutionary socialization of the land, because the land must belong to those who cultivate it. Unlike the Socialist-Revolutionaries, who proclaimed that the agrarian reform should be decided on a legitimate basis by the Constituent Assembly, Makhno argued that the peasants themselves should resolve the issue of land and proclaim it universal property without waiting for the decision of the "revolutionary government"19. The propaganda of this idea

19 Махно Н. Русская революция на Украине (от марта 1917 г. по апрель 1918 год). Париж. Б-ка Махновцев: Федерация анархо-комунист. групп Северной Америки и Канады. 1929. Кн. 1. 1929. С. 53-57. 
was received with enthusiasm by the peasantry. At congresses and assemblies, resolutions were passed on the transfer of land to the working population without redemption and the inalienable right of the working peasantry to declare landed, monastic and state lands public property. N. Makhno destroyed land documents and called for the free distribution of land to the peasants, which won their ardent support.

N. Makhno advocated the creation of communes, which he considered the highest form of social justice. Those who did not want to go to the commune could remain individual masters, but without the use of hired labour. Instead, the Bolsheviks, who at times were allies of Makhno, insisted on a communist version of solution of the agrarian issue. In an attempt to divide the peasantry, they divided it into the poor (supporters of the proletariat) and the kulaks (supporters of the bourgeoisie). The Makhnovists denied such a division and, on the contrary, focused on a "cohesive" labour union.

The general principles of agrarian policy were decided at congresses of Soviets of Peasants, Workers, and Insurgents. The resolution on the agrarian question, adopted on February 15, 1919, proposed to solve the agrarian problem on an all-Ukrainian scale on the following grounds: "All land in favour of socialism and the struggle against the bourgeoisie must pass into the hands of the working peasantry. Based on the principle that "no man's land" can be used only by those who cultivate it, the land should be used by the working peasantry of Ukraine free of charge according to the equal labour norm, i.e. it should provide the consumer norm on the basis of own labour" 20 .

Seeing the negative attitude of the peasantry to the Bolshevik policy in the countryside, the Makhnovists in 1919 called for the repeal of the Decree on the nationalization of land. They declared that all land confiscated from private owners should not come into the possession of the state, but into the possession and disposal of working peasants, who on the ground had to decide for themselves how to dispose of the land ${ }^{21}$. As can be seen, Makhno's agrarian policy was largely based on the Socialist-Revolutionary theory of socialization. An important difference with the SocialistRevolutionary approach was that the Makhnovists introduced into it a certain anarchic element, considered it legitimate for the peasants to actually redistribute the land, $n$ e waiting for certain orders or legal grounds from the

${ }^{20}$ Нестор Махно. Крестьянское движение на Украине. 1918-1921. Документы иматериалы. [ред.-упоряд. В. Данилов, Т. Шанин]. Москва. (РОССПЭН). 2006. C. 90.

${ }^{21}$ Жбанова К. Земельна політика Нестора Махна (1917-1921 рр.). Сіверянський літопис. 2013. № 4-6. С. 99. 
state. This position brought $\mathrm{N}$. Makhno great popularity and support among the peasants.

Regarding the political system that N. Makhno intended to create. In our opinion, it is necessary to pay special attention to his appeals and declarations, which often had a "powerless and anarcho-communist" character and actually implemented projects of government building, which claim the formation of certain elements of state structures. N. Makhno called on the population to start building a new life on anarchic, powerless principles. At the same time, realizing that the Soviets were popular among the peasants, he relied on their formation. Councils and land committees were formed on the ground and began to function as bodies of revolutionary power.

At the end of 1918, the Makhnovists won the "Free District" in southern Ukraine, which was independent of any government. In this territory N. Makhno made an attempt to create his own political entity, an "anarchist republic",22,

The political ideal of the Makhnovists was a society in which coercive state power was replaced by a system of public power, which was to stop the construction of a new bureaucratic system. Power, based on local selfgovernment and growing from it down to the mountain through congresses of Soviets, is the main principle of Makhnov's concept of a "free Soviet system". These councils were to become a kind of "socio-economic organizations" regulating production and social relations ${ }^{23}$. It is significant that the construction of local self-government bodies, like that of the SRs, was based on the "labour principle", i.e., only the working class had the right to elect and be elected to government bodies. The Military Revolutionary Council was a permanent body of power. There were also general congresses of peasants, workers and insurgents of the "Free District".

$\mathrm{N}$. Makhno adhered to left-wing political pluralism. The principle of the political strategy of the Makhnovist movement, beginning in 1919, was the platform of the "united revolutionary front", the union of "Soviet" parties. In addition to the anarchists (whose ideas were declared) there were organizations of the Left Socialist Revolutionaries, Mensheviks and Bolsheviks. In general, N. Makhno adequately assessed the real influence of political parties on the peasant masses. His detachments consisted mainly of non-partisan peasants, who primarily sought land and complete

22 Чоп B.M., Лиман I.I. Нащадки запорожців: Махновський рух у Північному Приазов”ї (1918-1921рр.). Мелітополь. Видавничий будинок Мелітопольської міської друкарні. 2019. С. 5.

${ }^{23}$ Савченко В.А. Нестор Махно. Харків. Фоліо, 2019. С. 55. 
independence from power and freedom of action. Unfamiliar with the theory of ideological anarchism, the peasant insurgents defended their own vision of a just system, which in some ways coincided with the declarations of anarcho-communism.

In the autumn of 1919, Makhno became disillusioned with the alliesBolsheviks, who declared a monopoly on the revolution for their party and embodied the anti-peasant policy of the "dictatorship of the proletariat". He put forward the idea of a "third social revolution" (after the first, the February (bourgeois) and the second, the October (communist) revolution. Its tasks were: the struggle against both the communist and the White Guard authorities and the development of self-government on the basis of nonpartisan "free Soviets" 24 , The Makhnovists also declared the need to protect the countryside from exploitation and enslavement by the city. Makhno himself argued that cities were an anachronism in the lives of free people and were therefore doomed. He believed that the power that spread from the city was as hostile to the peasants as the power of the state that exploited their labour ${ }^{25}$.

N. Makhno and the peasant insurgents considered persons of the "bourgeois class" as well as "Soviet commissars, members of punitive detachments, and emergency commissions" to be enemies of the working people $^{26}$. Modern researchers V. Verstyuk and V. Volkovynsky reduce the essence of the ideology of the Makhnovist movement to the peasantry's search for a "third way" in the revolution ${ }^{27}$. The order that emerged in the territory controlled by N. Makhno was a real alternative to both the Bolshevik (Communism) and White Guard (Capitalism) authorities - and aimed at protecting the interests of working peasants.

The peasants of southern Ukraine massively supported the slogans of N. Makhno and the anarchists because most other political forces advocated organized and sanctioned by state bodies transformations in the agrarian and socio-political spheres. Instead, the Makhnovists advocated their immediate implementation by the peasants themselves, which gained widespread support among the masses. The peasant insurgents defended their own

24 Нестор Иванович Махно: Воспоминания, материалы и документы. сост. В.Ф. Верстюк. Київ : Дзвін. 1991. С. 156-163

${ }^{25}$ Грицак Я.Й. Нариси історії України: формування модерної української нації XIX-XX ст. [навч.посібник]. Київ. Генеза. 1996. С. 149.

${ }^{26}$ Нестор Иванович Махно: Воспоминания, материалы и документы. сост. В.Ф. Верстюк. Київ : Дзвін. 1991. С. 154-155.

27 Чоп В.М. Махновський рух в Україні 1917-1921 рр.: проблеми ідеології, суспільного та військового устрою : автореф. дис. ... кандидата історичних наук. Запоріжжя, 2002. С. 5. 
interests in a just society, which in some ways coincided with certain principles of the doctrine of anarchism. The "free district" seemed to anarchist ideologues of the movement and peasant insurgents not only the ideal of the social order, but also, in a way, the practice of order in the territories occupied by the insurgents. The researcher of Makhnovism V. Chop notes that its ideology synthesized the ideas of theoretical anarchism, folk worldview and Zaporizhzhia traditions ${ }^{28}$.

The phenomenon of Makhnovism was best reflected in the following discourses: "socialization of the land", "comrades peasants, working population", "social revolution", "kingdom of freedom and equality", "anarchic commune", "labour and capital", "for exploited against exploiters", "Decide your own destiny", "life without parties and without state political power", "freely elected workers 'and peasants' councils", "away from the White Guards", "for free councils without communists", "away from the commune", "the real Soviet system".

Thus, the social base of Makhnovism was the Ukrainian peasantry. It was in the Makhnovist movement that the peasantry proved to be the subject of real politics. His socio-economic program reflected the peculiarities of the peasant mentality associated with free life and management of their own land, based on the traditions of the Ukrainian Cossacks. Therefore, the main requirements were: free peasant land use and elected councils as selfgoverning bodies without state intervention, i.e. the implementation of the slogan "land and freedom" in the form of a free labour community.

The Makhnovists declared a decisive clash between the idea of a free, powerless organization (they believed that this idea was already accepted by large masses of Ukraine) and the idea of political power (monarchical, communist or bourgeois-republican). In the end, this struggle ended in victory for the Bolsheviks, who embodied the idea of a strong state. At the same time, a kind of peasant republic, the so-called "Free District", was not the embodiment of anarchist ideals of statelessness, and the socio-political practice of the Makhnovist movement gave rise to a quasi-state formation with its own system of government and political program. The ideas of anarchism about a stateless, powerless, free society did not correspond to the realities of life.

${ }^{28}$ Чоп В.М. Союз і змова: обставини підписання і розриву військово-політичної угоди РПАУ /махновців/ та УНР (вересень 1919 р.). Наукові праці історичного факультету Запорізького державного університету. Запоріжжя : Просвіта. 2005. Вип. ХIX. С. 206. 


\section{Right agrarianist peasant-centric discourse (UDAP)}

Beginning in the spring of 1917, left-wing and far-left parties dominated the Ukrainian political space. They called for agrarian socialization, the abolition of private ownership of land and the endowment of the landless peasantry, which led to the radicalization of the peasant masses and chaos in the countryside. At the same time, the Ukrainian agrarian society, along with the poor peasantry, was represented by a certain share of peasant owners and landowners.

To defend their interests, the pro-Ukrainian ownership in 1917 created the Ukrainian Democratic-Agrarian Party (UDAP), which was based on a peculiar, according to its founders, specific ideology of Ukrainian society, based on its own historical and spiritual heritage and powerful potential of the peasant-grain grower class. By their social affiliation, the party members were landowners, representatives of the wealthy and middle classes of the peasantry, and the intelligentsia. The "grain growers" discourse emphasized that the party would resist and reflect the interests of agricultural producers, especially landowners, peasants who work on their own land. In addition, often illiterate peasants perceived the party, looking at its name. And the very concept of "grain growers" had a positive association with them.

Some Ukrainian peasants and landowners believed that socialization would lead to socio-economic ruin. It was claimed to be in line with Russian realities and based on the psychology of a community where there was almost no private ownership of land. Insisting on this fundamental difference between land tenure in Ukraine and Russia, they tried to develop their own Ukrainian path of agrarian reform to ensure a policy of economic prosperity, social balance and stability. Since the land of the owners is the material basis of the agricultural political force, argarianist transformations must be carried out on the basis of private property rights.

In the "Essay on the UDAP Program", one of the leaders of the Democrats-agrarians, V. Lypynsky, outlined the principles of "grain grower ideology", the program of actions and political tactics of the grain grower movement. At the heart of the ideology are the concepts of "grain grower", "grain grower class". Although V. Lypynsky later defined the concept of the grain grower class as "a group of families who own their own land and produce bread on their own land" ${ }^{, 29}$, already in 1917, the political discourse "grain grower" meant a significant part of agrarian society from the poor peasant to the landlord-landowner, i.e., all those who worked in agriculture

29 Липинський В. Листи до братів-хліборобів про ідею і організацію українського монархізму. Київ-Філадельфія. Східноєвропейський дослідний інститут ім. В.К. Липинського. 1995. С. 72. 
and belonged to one productive class. In contrast to the class approach of the left parties, this approach was marked by a consolidating spirit and a unifying approach of the general democratic social order. The grain grower class should become the basis of the new Ukrainian state and economic elite and combine "the young energy of the Ukrainian peasantry with the state wisdom of the descendants of the hetman's and officers' families" ${ }^{\prime 30}$.

The UDAP noted that land issue was the most important thing for Ukraine. Democrats-agrarians have developed their own version of agrarian reform. Given that Ukraine has its own peculiarities of agrarian development, its own national traditions of land use, different from the Russian-communal ones, they insisted that the agrarian question should not be decided by the Russian Constituent Assembly, but by the Sejm elected at the Ukrainian Constituent Assembly ${ }^{31}$.

The agrarian issue was proposed to be solved on the basis of preservation of private property, by recognizing and ensuring two forms of land tenure and land use - private and lease. The state had to create a national land fund, which would be replenished by appropriation for the purchase of land above a certain norm set by law. The land fund was to be divided into farms of the "working Ukrainian peasantry", the size of which would correspond to the optimal economic norm for a certain area (these hamlets would be transferred to the peasants for life and hereditary lease without the right of division) $)^{32}$. The important concepts of "labour" and "hamlet" important for the peasant consciousness, which were associated with their own economy, independent of "master and city" and happy work in nature, were successfully involved in this discourse.

Peasant allotment land should become the full property of grain growers. At the same time, despite guaranteeing the inviolability of private land ownership, the state should warn against excessive concentration of land in one hand (so that huge landowners' latifundia disappear), as well as prevent land speculation. The confiscation of large plots of land could provoke resistance, while their redemption by the peasants would give them a sense of ownership and eliminate the threat of social-class confrontation ${ }^{33}$.

30 Липинський В.К. Нарис програми Української демократичної хліборобської партії. Матеріали до програми. Видання Української демократичної партії. Лубни. 1917. C. 6-7.

${ }^{31}$ Ibid. C. 137.

32 Українські політичні партії кінця XIX - початку XX століття: програмові і довідкові матеріали. Упоряд. В.Ф. Шевченко та ін. Київ. 1993. С. 137.

${ }^{33}$ Гай-Нижник П.П. В. Липинський та УДХП в теорії і практиці українського державотворення і політичного націонал-консерватизму (1900-1920рр.). Гілея. Науковий вісник. 2018. Вип. 129. С. 310. 
Ukrainian State must aim to accelerate the objective process of the transfer of landed estates to the hands of the peasantry and, at the same time, to develop organizational and legal principles for this process. As a result of agrarian transformations, "Free Grain Grower Ukraine" was to become a land of highly developed, intensive farming. At the same time, it was seen that the Ukrainian grain growers would be united into powerful cooperative societies.

The central place in the concept of the formation of Ukrainian statehood is given to the grain grower class, which should be the main subject of the political process. This is argued by the fact that the traditional peasant-grain grower is the bearer of the national-state and cultural experience of the Ukrainian people and to protect their land is interested in building an independent state. The agricultural class as an important productive class and the mainstay of the state and order can exist only on the basis of private ownership of land. Owners-grain growers, having an economic incentive, providing for themselves and society, should become a kind of "strong middle class" and a powerful foundation of state existence.

Taking into account that the peasantry dominates in the Ukrainian social structure and economy, V. Lypynsky and his associates argue that political power in Ukraine should belong primarily to the representatives of the Ukrainian peasantry. Outlining the socio-cultural contradiction between the Ukrainian countryside and the non-Ukrainian city, they note that the city should not "dictate its will to the Ukrainian countryside". Finally, the allencompassing peasant-centricity of the party-political discourse of the Democrats-agrarians contains the statement "Ukraine is a land of grain growers, and the Ukrainian state must become a state of grain growers" 34 .

Regarding the principles of state building and the formation of government bodies, the UDAP program outlines a democratic project of the state system, and focuses on the principle of sovereignty of the Ukrainian people. The party must defend the republic, in which the legislature will belong to the parliament (Sejm), and the executive - to the General Secretariat (Council of Ministers). Authorities were to be elected through democratic elections on the basis of equal, popular, secret, direct, proportional law without any restrictions on social, national or religious grounds. State laws that guarantee universal human rights must be based on democratic principles. The democratic elections of all power structures from top to bottom, given the significant predominance of the rural population,

${ }^{34}$ Українські політичні партії кінця XIX - початку XX століття: програмові і довідкові матеріали. Упоряд. В.Ф. Шевченко та ін. Київ : Консалтинг-Фенікс 1993. C. 133. 
should provide political power in Ukraine to the Ukrainian peasantry. The SRs also called for the political domination of the peasantry, but according to their class approach they were to be poor and middle peasants, and the UDAP wanted them to be strong grain growers-landowners.

The movement of Democrats-agrarians also had a Cossack dimension. It began with Lubny district in Poltava region, where among landowners there was a significant percentage of descendants of settled free-spirited Cossacks who kept ancient traditions in self-government and everyday life. For the most part, in the same region, the party conducted its organizational, political and propaganda activities and attracted the largest number of agricultural activists to political life. Separate centres operated in the Kherson region, as well as in Kyiv, Katerynoslav, and Kharkiv. However, the UDAP failed to reach an all-Ukrainian scale, did not gain the proper mass, nor significant influence among the peasants. This is explained by the fact that on the ground most of the UDAP cells consisted of intellectuals (often peasants did not trust the intelligentsia), "which could not attract a real grain grower to the party and was in fact a typical Ukrainian organization of intellectuals ${ }{ }^{35}$.

In the future, the theoretical foundations of agricultural policy, developed by the UDAP, formed the basis of the achievements of agrarian reform of Hetman P. Skoropadsky. They provided for the preservation of private ownership of land, redemption of land from large landowners to endow smallholder peasants. However, the Hetman did not have time to carry out this reform ${ }^{36}$.

V. Lypynsky and Democrats-farmers at the same time spoke out against the harmful to the peasants "chaos of private capitalist economy" 37 , and against socialist transformations, which will take away from the peasant private ownership of land and destroy agricultural production. Thus, professing both anti-capitalism and anti-communism, their "third way" was moderate reforms that would create a large layer of landowners who would be a bulwark against the nationalization of communism and, on the other

35 Україна XX ст.: суспільно-політичні моделі національної держави (державницька ідеологія та програмні засади провідних українських політичних партій і громадсько-політичних об’єднань). П.П. Гай-Нижник (керівник проекту, упоряд. і наук. ред.). Київ, 2018. С. 50.

Корновенко С. В. Аграрна політика Гетьманату: теоретичний аспект. Украӥнський селянин. 2004. Вип. 8. С. 211-214.

37 Липинський В.К. Нарис Української демократичної хліборобської партії. Матеріали до програми. Видання Української демократичної партії. Лубни, 1917. C. 19. 
hand, will oppose the elements of the capitalist market, which will save peasant farms from capital exploitation and ruin.

Thus, the party-political peasant-centric discourse of the UDAP consisted of the following concepts: "grain growers", "agrarian nation", "Ukrainian peasantry", "the land issue is most important for us", "land ownership", "fertile land", "labour", "hamlets", "farming", "powerful cooperative societies", "tradition", "Free grain grower Ukraine", "the city should not dictate its will to the Ukrainian countryside", "state of grain growers", "democracy".

In conditions of the dominance of left and far-left radical parties, the creation of the UDAP was caused by the need to represent in the Ukrainian political space non-socialist, national ownership forces of conservative orientation, which formed a certain part of Ukrainian agrarian society. The main subject and social basis of socio-political transformations was proclaimed the farming class - land workers, landowners who produced agricultural products and were interested in stability, maintenance of law and order and resisted the revolutionary chaos.

\section{CONCLUSIONS}

Thus, from the point of view of ideological guidelines, strategies and tactics of realization of political goals, the party-political peasant-centric discourse of the revolutionary period of 1917-1921 in Ukraine was divided into the following main types:

Socialist-Socialist-Revolutionary (USRP): 1) resolution of the agrarian issue on the basis of socialization, abolition of private ownership of land, land confiscated from owners and transferred free of charge to peasants who were to authorize the All-Russian Constituent Assembly, according to state laws and regulations transformation; 2) the peasant - the main subject of state-building, the model of statehood - the power of the Soviets (Labour Councils, former zemstvos and the Council of Workers' Peasants' and Soldiers' Deputies) embodies the class democracy of the working class, which based on suffrage enjoyed only by workers (peasants, workers), the working intelligentsia) the peasants must dominate most of the authorities, there must be a class struggle with the bourgeoisie and the landlords;

anarchist-Makhnovist (Makhnovist movement): 1) the agrarian issue is solved on the basis of socialization, abolition of private ownership of land, land is confiscated from owners and transferred free of charge to peasants who do not wait for the adoption of laws and orders of the government themselves divide the land; 2) the peasant is the main subject of social relations, the stateless and powerless model ("Free District") is proclaimed, and the power of the Soviets (Soviets of Workers', Peasants', and Soldiers' Deputies) is declared to be a contradiction. the rights enjoyed only by 
workers (peasants, workers, labour intelligentsia), the peasants have a predominant influence on the government, the struggle must be waged both against the power of the bourgeoisie (White Guards) and the "dictatorship of the proletariat" (Bolsheviks);

conservative-grain-grower (UDAP): 1) agrarian reform with the preservation of private property, sanctioned by the Ukrainian Sejm, according to the developed laws, the land passes to the peasants for ransom, the creation of hamlet households (farms) as a kind of "middle class"; 2) the main subject of state-building - the grain grower class, which means all agricultural producers, the model of the state - democratic government based on universal suffrage, the formation of a new elite as a symbiosis of wealthy grain growers and descendants of the officers, the rule of law, class cooperation and social partnership.

The mobilization possibilities of these discourses in the countryside depended on the extent to which they resonated with the peasants' mental guidelines and adapted to the changing socio-political situation of the time. Calls for the socialization of the land and the power of the workers, the power of the Soviets, were close to the peasant consciousness, so socialistSR and anarchist-Makhnovist discourses were popular with the general peasantry and made him a supporter of these political forces. However, a significant difference in the ways of their implementation - legally through state authorities in the socialist-SR version, and the peasants themselves, without state influence, in the anarchist-Makhnovist, as practice shows, gave the latter much more opportunities to involve the peasantry in the implementation of their political ideas. Conservative grain grower discourse, based on private property and democracy, at that time corresponded to the level of consciousness of a small segment of the agricultural population and had limited mobilization opportunities in the countryside.

Each of these party-political peasant-centric discourses offered their "third" way of socio-political development, but due to the revolutionary realities of the time, it was not realized.

\section{REFERENCES}

1. Багатопартійна українська держава на початку XX ст. : Програмні документи перших українських політичних партій. Упор. В.С. Журавський. Київ : Пошук, 1992. 96 с.

2. Бевз Т. Між романтизмом і реалізмом (сторінки історії УПСР). Київ : Інститут політичних і етнонаціональних досліджень НАН України. 1999. 272 с.

3. Винниченко В. Відродження нації: (Історія української революції [марець 1917 р. грудень 1919 р.]). [в 3 ч.]. Київ-Відень : [Дзвін]. 1920. Ч. 1. 348 с. 
4. Гай-Нижник П.П. В. Липинський та УДХП в теорії і практиці українського державотворення і політичного націонал-консерватизму (1900-1920 рр.). Гілея. Науковий вісник. 2018. Вип. 129. № 2. C. $305-322$.

5. Галушко К. «Хліборобська ідеологія» В. Липинського у системі східноєвропейського аграризму. Український історичний збірник. 2000. № 2. С. 164-200.

6. Грицак Я.Й. Нариси історії України: формування модерної української нації XIX-XX ст. [Навч. посібник]. Київ : Генеза. 1996. $360 \mathrm{c}$.

7. Жбанова К. Земельна політика Нестора Махна (1917-1921 рр.). Сіверянський літопис. 2013. № 4-6. С. 96-101.

8. Земельный вопрос. Голос села. Охтирка. 1917. 2 липня. (№ 1). С. 1.

9. Ковалевський М. При джерелах боротьби: спомини, враження, рефлексії. Інсбрук. "Biblos". 1960. 720 с.

10. Корновенко С.В. Аграрна політика Гетьманату: теоретичний аспект. Украӥнський селянин. 2004. Вип. 8. С. 211-214.

11. Корновенко С.В. Суб'єктний складник аграрного питання як одна $з$ передумов Української революції 1917-1921 рр. Украӥнський історичний журнал. 2017. № 4. С. 83-94.

12. Корновенко С. Хутірська філософія П. Куліша: біля джерел українського аграризму. Украӥнський історичний журнал. 2020. № 5. C. 64-76.

13. Kornovenko S., Pasichna Y. Eastern european agrarianism. Ukrainian intellectual space in the late 19th and early 20th centuries. Украӥнський селянин. 2019. Вип. 22. С. 24-29.

14. Корреспонденции. Черниговская земская газета. 1917. 2-16 мая (№ 35-36). С. 9.

15. Липинський В. Листи до братів-хліборобів про ідею і організацію українського монархізму. Київ - Філадельфія. Східноєвропейський дослідний інститут ім. В.К. Липинського. 1995. 470 с.

16. Липинський В.К. Нарис програми Української демократичної хліборобської партії. Матеріали до програми. Видання Української демократичної партії. Лубни, 1917.31 с.

17. Махно Н. Русская революция на Украине (от марта 1917 г. по апрель 1918 год). Париж. Б-ка Махновцев : Федерация анархокомунист. групп Северной Америки и Канады. 1929. Кн. 1.216 с.

18. Нестор Иванович Махно: Воспоминания, материалы и документы. сост. В.Ф. Верстюк. Київ : Дзвін. 1991. 192 с.

19. Нестор Махно. Крестьянское движение на Украине. 1918-1921. Документы иматериалы. [ред.-упоряд. В. Данилов, Т. Шанин]. Москва. (РОССПЭН). 2006. 1000 c. 
20. Программа партии социалистов-революционеров. [1906 г.]. Сборник программ политических партий в России. Под ред. В. Водовозова. Вып. 3. СПб., 1906. С. 14-27. URL: http://docs.historyrussia.org/ru/ nodes/74934-programma-partii-sotsialistov-revolyutsionerov-1906-g.

21. Савченко В.А. Нестор Махно. Харків : Фоліо, 2019. 123 с.

22. Україна XX ст.: суспільно-політичні моделі національної держави (державницька ідеологія та програмні засади провідних українських політичних партій і громадсько-політичних об'єднань). П.П. ГайНижник (керівник проекту, упоряд. і наук. ред.). Київ, 2018. 705 с.

23. Український національно-визвольний рух. Березень-листопад 1917 року. Документи і матеріали. Упоряд. : В. Верстюк (керівник) та ін. Київ. Видавництво імені Олени Теліги. 2003. 1024 с.

24. Українські політичні партії кінця XIX - початку XX століття: програмові і довідкові матеріали. Упоряд. В.Ф. Шевченко та ін. Київ : Консалтинг-Фенікс. 1993. 336 с.

25. Чоп B.М., Лиман I.I. Нащадки запорожців: Махновський рух у Північному Приазов”і (1918-1921рр.). Мелітополь : Видавничий будинок Мелітопольської міської друкарні. 2019. 609 с.

26. Чоп В.М. Махновський рух в Україні 1917-1921 pp. : проблеми ідеології, суспільного та військового устрою : автореф. дис. ... канд. істор. наук. Запоріжжя, 2002. 20 с.

27. Чоп В.М. Союз і змова: обставини підписання i розриву військово-політичної угоди РПАУ /махновців/ та УНР (вересень 1919 р.). Наукові праиі історичного факультету Запорізького державного університету. Запоріжжя : Просвіта. 2005. Вип. XIX. С. 206-221.

28. Шаповал М. Велика революція і українська визвольна програма. Виклади в Америці. Прага : Вільна Спілка. 1927. 324 с.

29. Шаповал М.Ю. Революційний соціялізм на Україні: [книга 1]. Відень. Борітеся - Поборете. 1921. Кн.1. 256 с.

30. Що таке селоспілка? Вільне слово. 1917. 5 липня (№ 7). С. 1. 